BIOMEDICAL AND BIOSOCIAL ANTHROPOLOGY
$\begin{gathered}\text { Official Journal of the International Academy } \\ \text { of Integrative Anthropology } \\ \text { journal homepage: http://bba-journal.com }\end{gathered}$

\title{
Somatotypological features of acrobat girls in different periods of ontogenesis
}

Sarafinyuk L. A. ${ }^{1}$, Khapitska O. P. ${ }^{1}$, Yakusheva Yu. I. ${ }^{1}$ Ivanytsia A. 0. ${ }^{1}$, Sarafinyuk P. V.

${ }^{1}$ National Pirogov Memorial Medical University, Vinnytsya, Ukraine

${ }^{2}$ Vinnitsa State Pedagogical University named after Mikhail Kotsyubinsky, Vinnytsya, Ukraine

\section{ARTICLE INFO}

Received: 5 July, 2018

Accepted: 24 August, 2018

UDC: $572.512 .7: 796.4$

\section{CORRESPONDING AUTHOR}

e-mail: Isarafinyuk@gmail.com Sarafyniuk L. A.
The somatotypological characteristic of acrobats in the literature is insufficiently disclosed, especially from the position of the role of sports selection, training and competitive activities in the formation of somatotype in athletes, whose professional activity is marked by coordination, rhythm and artistic movements, and the early onset of the impact of intense physical activity on their body. The purpose of the work is to establish the peculiarities of the components of the somatotype of acrobats with a high level of sportsmanship of prepubertal, pubertal and postpubertal age. We conducted a survey of 122 girls acrobats of high-level sports skills. As a control group, 126 girls were examined, who were not engaged in sports and studied in schools of Vinnytsia. The girls' passport age was between 8 and 21 years old. In order to determine the biological age, we used the scheme Avtandilov G. G. (1990). The examined girls were divided into three groups according to the degree of biological maturity: prepubertal period (36 acrobats and 39 girls of the control group); puberty period (31 acrobats and 35 girls of the control group); postpubertal period (55 acrobats and 59 girls of the control group). The somatotypological study was performed according to the estimated modification of the Heath-Carters method (1990). The analysis of the obtained results was carried out in the licensed package "Statistica 5.5" using parametric methods of estimation of indicators. It was found that in the prepubertal period of the ontogenesis in the acrobat and in the girls who were not engaged in sports, the group somatotype was ecto-mesomorphic. In this period, the fatty component of the somatotype in acrobats was significantly lower, and mesomorphic - significantly higher than that of non-sports girls. In the puberty period, the somatotype in control and acrobats had distinct features of the ecto-mesomorphic type. It was found that acrobats in this period had a greater linearity of the body, as evidenced by the significantly higher values of their ectomorphic component of the somatotype. In addition, the size of the endomorphic component was significantly lower in athletes than in the control group. In the postpubertal period of ontogenesis, the F- and L-components were not significantly different, unlike in the previous period, which was characterized by intense puberty development. Acrobats only showed a significant predominance of the mesomorphic component of the somatotype. It can be concluded that the peculiarities of acrobatic sports activity in prepubertal, puberty and postpubertal age have the most significant effect on the development of the fatty and muscular components of the somatotype.

Keywords: somatotype, sports acrobatics, periods of ontogenesis, girls.

\section{Introduction}

In contrast to the usual physical training in the purposeful sporting activity, the task of training athletes to achieve their ultimate motor, psychological and functional results is solved $[13,17]$. Therefore, in the process of training and competition athletes feel the burden on the body as a whole and on its separate systems. The experience of clinical and athletic practice really convinces in the ambiguity of changes in the whole organism under various burdensome conditions $[11,12,18,20]$. The somatotypological characteristic of acrobats in the literature is not sufficiently revealed, especially from the standpoint of the role of sports selection, training and competitive activities 
in the formation of somatotype in athletes, whose professional activity is marked by coordination, rhythm, artistic movements, and the early onset of the effects of intense physical activity on their body in different periods of ontogenesis.

Ontogenetic approach in studying morphofunctional features of the organism is based on the fact that within the same annual age-sex group there are individuals with different anatomical and physiological level of development [8]. First of all, it's relevant for athletes. Indicators of their biological age are the main criterion for assessing the state of the whole organism $[5,16]$. Determining the stages of development of secondary sexual characteristics is particularly popular, quite reliable and affordable method among many methods for assessing biological age [1, 15, 19, 23].

The purpose of the work is to establish the peculiarities of the components of the somatotype of acrobats with a high level of sportsmanship of prepubertal, pubertal and postpubertal age.

\section{Materials and methods}

We conducted a survey of 122 girls acrobats of highlevel sports skills, among them the first adult rank had 24 athletes, 38 girls were candidates for masters of sports, 46 - masters of sports, 14 - masters of international class sports. Many of them took prizes in the championships of Ukraine, international tournaments, World and European championships. Among them were 13 World champions, 8 absolute champions of Europe. Experience in sports in all cases was more than three years. As a control group, 126 girls were examined, who were not engaged in sports and studied in schools of Vinnytsia. The girls' passport age was between 8 and 21 years old. But, as you know, for many scientific and practical purposes it is not enough to group children and adolescents in only one calendar year, it is necessary to take into account the general biological development of the person. To this end, we used the scheme [2], which is based on the determination of the stages of development of the hair in the axillae $(A x)$ and the pubic $(P)$, the mammary glands (Ma) and the age of the onset of the first menstruation (Me).

The subjects were divided according to the degree of biological maturity into three groups:

- the prepubertal period (the appearance of pubic fishing), to it belonged 36 acrobats and 39 girls of the control group;

- puberty period (puberty to the appearance of menarche), to it belonged to 31 acrobats and 35 girls of the control group;

- postpubertal period (fixed and ending puberty, the body reaches a definitive size), to it belonged 55 acrobats and 59 girls of the control group.

All surveyed patients had a somatotypological study based on the estimated modification of the Heath-Carter method [6]. The analysis of the obtained results was carried out in the licensed package "Statistica 5.5" using parametric methods of estimation of indicators.

\section{Results}

The average calendar age in the groups of athletes and the control had significant differences, so in the prepubertal period of the ontogenesis acrobats had an average age $(10.13 \pm 0.24)$ years, and girls who were not engaged in sports - (9.652 \pm 0.351$)$ years; in the puberty period: acrobats - (13.35 \pm 0.32$)$ years, control group - $(11.51 \pm 0.26)$ years; in the postpubertal period: acrobats $-(16.83 \pm 0.22)$ years, girls in the control group - $(16.04 \pm 0.38)$ years. Thus, we found that athletes had a significantly lower $(p<0.05)$ calendar age compared to girls who were not engaged in sports in the puberty period of ontogenesis.

After a somatotypological analysis, it was found that in the prepubertal period of the ontogenesis in acrobats, the somatotype can be characterized as ecto-mesomorphic (1.024 - 3.224 - 4.065), and in girls who were not engaged in sports as ectomorphic $(2,380-2,744-4,043)$, which is confirmed by the mean value of the endomorphic $(F)$, mesomorphic (M) and exomorphic (L) points. The difference in magnitude with which the endomorphic component of the somatotype was expressed among the athletes and the girls in the control group was statistically significant $(p<0.001)$. In athletes, the significance of the mesomorphic component of the somatotype was significantly greater than that of the control $(p<0.01)$. The magnitude of the ectomorphic component has almost the same mean values in both groups of comparison (Table 1).

In the control group and in athletes of prepubertal age, we conducted a percentage distribution of different constitutional types. It was found that in $81.2 \%$ of acrobats and $61.5 \%$ of non-sports girls reported an ectomesomorphic somatotype. Mesomorphic type of body structure is registered in $18.8 \%$ of athletes and $23.1 \%$ of control group. Endomorphic type in this age group was not found, but $15.4 \%$ of girls who did not engage in sports belonged to the meso-endomorphic constitutional type.

In the puberty period of ontogenesis, the somatotype of the girls of both groups of comparison had the pronounced features of the rice of the mesomorphic ectomorph. The average values of components of the somatotype in acrobats were: 1.291 - 3.936 - 4.254; in the control group girls: 2,235 $-3,262-3,273$. Girls belonging to this biological age did not have a significant difference in the size of the mesomorphic component. However, we noted the significant difference in the score of the endomorphic component, which is higher in non-athletes $(p<0.001)$ and ectomorphic, which is higher in acrobats $(p<0.01)($ Table 2$)$.

In the acrobats of puberty period ontogenesis the

Table 1. The value of components of the somatotype (points) in girls of prepubertal age.

\begin{tabular}{|c|c|c|c|c|}
\hline $\begin{array}{c}\text { Components of } \\
\text { the somatotype }\end{array}$ & $\begin{array}{c}\text { Acrobats } \\
(\mathrm{M} \pm \mathrm{m})\end{array}$ & $\begin{array}{c}\text { Control group } \\
(\mathrm{M} \pm \mathrm{m})\end{array}$ & $\mathrm{t}$ & $\mathrm{p}$ \\
\hline $\mathrm{F}$ & $1.024 \pm 0.030$ & $2.380 \pm 0.061$ & 7.266 & $<0.001$ \\
\hline $\mathrm{M}$ & $3.224 \pm 0.091$ & $2.744 \pm 0.140$ & 2.895 & $<0.01$ \\
\hline $\mathrm{L}$ & $4.065 \pm 0.165$ & $4.043 \pm 0.187$ & 0.196 & $>0.05$ \\
\hline
\end{tabular}


Table 2. Values of components of somatotype (points) in girls of puberty age.

\begin{tabular}{|c|c|c|c|c|}
\hline $\begin{array}{c}\text { Components of } \\
\text { the somatotype }\end{array}$ & $\begin{array}{c}\text { Acrobats } \\
(\mathrm{M} \pm \mathrm{m})\end{array}$ & $\begin{array}{c}\text { Control group } \\
(\mathrm{M} \pm \mathrm{m})\end{array}$ & $\mathrm{t}$ & $\mathrm{p}$ \\
\hline $\mathrm{F}$ & $1.291 \pm 0.053$ & $2.235 \pm 0.011$ & 7.216 & $<0.001$ \\
\hline $\mathrm{M}$ & $3.936 \pm 0.155$ & $3.262 \pm 0.194$ & 1.324 & $>0.05$ \\
\hline $\mathrm{L}$ & $4.254 \pm 0.151$ & $3.273 \pm 0.180$ & 3.095 & $<0.01$ \\
\hline
\end{tabular}

Table 3. Significance of components of somatotype (points) in girls of postpuberty age.

\begin{tabular}{|c|c|c|c|c|}
\hline $\begin{array}{c}\text { Components of } \\
\text { the somatotype }\end{array}$ & $\begin{array}{c}\text { Acrobats } \\
(\mathrm{M} \pm \mathrm{m})\end{array}$ & $\begin{array}{c}\text { Control group } \\
(\mathrm{M} \pm \mathrm{m})\end{array}$ & $\mathrm{t}$ & $\mathrm{p}$ \\
\hline $\mathrm{F}$ & $2.001 \pm 0.083$ & $2.145 \pm 0.073$ & 1.324 & $>0.05$ \\
\hline $\mathrm{M}$ & $3.435 \pm 0.132$ & $2.621 \pm 0.110$ & 2.535 & $<0.05$ \\
\hline $\mathrm{L}$ & $3.136 \pm 0.147$ & $3.125 \pm 0.174$ & 0.043 & $>0.05$ \\
\hline
\end{tabular}

dominant constitutional type was ecto-mesomorphic, which is represented in $80.5 \%$ athletes, endomorphic is not detected, and mesomorphic expressed only in $19.5 \%$ of the surveyed. In the control groups, it was noted that the ectomesomorphic type was in $35.7 \%$ of girls, ectomorphic $22.8 \%$, mesomorphic - $14.6 \%$, middle intermediate $-20.0 \%$, and $2.9 \%$ of persons met endomorphic somatotype.

In postpubertal period of ontogenesis in acrobats, the mean score of endomorphy is 2.001; mesomorphy - 3.435; ectomorphy - 3.136. In non-sports girls, the following expression of the mean group somatotype was according: $2.145-2.621-3.125$. In this age period, the value of the endomorphic and ectomorphic components of the somatotype did not differ significantly between the comparison groups. But the acrobats had a significantly higher magnitude of the mesomorphic component of the somatotype (Table 3).

It should be noted that in the postpuberty period ontogenesis acrobats belonged to 5 types of somatotypes, but among acrobats, as in previous age periods, the ectomesomorphic (42.2\%) constitutional type dominated, and the mesomorphic was represented in $35.4 \%$ of girls, ectomorphic - in $7.7 \%$, endo-mesomorphic - in 2, $2 \%$, average intermediate - in $15.5 \%$. The girls in the control group were classified in 6 constitutional types: the most common variant of the somatotype was ecto-mesomorphic (39.0\%), ectomorphic was detected in $22.0 \%$ of subjects, mean intermediate $15.4 \%$, endo-mesomorphic - $13.4 \%$, mesomorphic - at $6.8 \%$, endomorphic - in $3.4 \%$ of the examined control group.

\section{Discussion}

After comparing the calendar year between acrobats and girls in the control group in the puberty period of ontogenesis, we found that athletes had significantly lower $(p<0.05)$ calendar years compared to non-athletes, which indicates a significant retardation of the indicators of puberty in acrobats, which, in our opinion, may be due to the characteristics of sports selection and training-competitive sporting activities. Significant retardation in the rate of puberty and the biological maturity of the athlete's body was detected in other scientific studies [3, 14]. In works Davydov V. Yu. et al. $[9,10]$ after conducting the analysis of conformity of biological age with passport at athletes aged 7-18, engaged in group acrobatics, it was found that the majority (68\%) of the surveyed belonged to the retardation type of development. Lack of biological age from passport to acrobats of different ranks of high level of athletic skill was, according to their data, on average 2 years. The authors consider such retardation of puberty as a consequence of hereditary factors, which deepen intensive workouts, deficiency of the total body mass, in particular, its fat component.

In our study, it was also found that the magnitude of the endomorphic component of the somatotype, which reflects the overall fattening, in acrobats in different periods of pubescence, is significantly lower than in girls of the control group. In the prepubertal period of ontogenesis, acrobats are characterized by a relative elongation of the body with adequate development of muscle-bone elements, and girls of the control group have a significant predominance of ectomorphism over almost uniformly pronounced components of mesomorphism and endomorphism. In this period in acrobats, the fat component of the somatotype is significantly lower, and the muscular-bone (mesomorphic) is significantly higher than in non-sports girls. In the puberty period, the somatotype in control and acrobats had distinct features of the ecto-mesomorphic type. It was found that acrobats in this period had a greater linearity of the body, as evidenced by the significantly higher values of their ectomorphic component of the somatotype. In addition, in athletes the value of the endomorphic component was significantly lower. In the postpubertal period of ontogenesis, the magnitude of the F- and L-components, unlike in the previous period, characterized by intense puberty development, did not differ significantly. But acrobats were markedly higher values of the mesomorphic component of the somatotype. One can conclude that the features of acrobatic sports activities have the most significant effect on the development of the fat and muscle components of the somatotype, which does not deny the results of other scholars $[4,7]$.

The medical and biological basis in the practical work of the trainer provides an opportunity for highly professional, scientifically grounded sports selection, rational construction of the training process, forecasting of technical results based on the morphological criteria of the athlete's somatotype. It is known that athletes with certain constitutional features have advantages in that, or in another kind of sport [21, 22, $24,25]$. Modern practice of selection of young athletes presents quite certain and rather rigid requirements to their morphological and functional indicators. Therefore, the determination of somatotypological affiliation and the score assessment of individual components of the somatotype may serve as reliable prognostic markers during sport selection.

\section{Conclusions}

1. It is established that in all periods of ontogenesis, the value of the endomorphic component of the somatotype in 
acrobats girls is lower than in the control group. The development of the mesomorphic component predominates in athletes in the pre- and postpubertal periods. The value of the ectomorphic component is significantly higher compared to non-athletes only in acrobats of puberty age.

2. It was established that acrobats before the end of puberty period were a homogeneous group with a significant predominance of ecto-mesomorphic somatotype (more than

\section{References}

[1]Alaux, C., Soubeyrand, S., Prado, A., Peruzzi, M., Maisonnasse, A., Vallon, J. ... Conte, Y. (2018). Measuring biological age to assess colony demographics in honeybees. PLOS ONE. 13(12): e0209192. https://doi.org/10.1371/ journal.pone.0209192

[2] Avtandilov, G. G. (1990). Medical morphometry. Moscow: Medicine.

[3] Bacciotti, S., Baxter-Jones, A., Gaya, A., \&Maia, J. (2017). The physique of elite female artistic gymnasts: a systematic review. J. Hum. Kinet., 58, 247-259. doi: 10.1515/hukin-2017-0075

[4] Bacciotti, S., Baxter-Jones, A., Gaya, A., \& Maia, J. (2018). Body physique and proportionality of Brazilian female artistic gymnasts. J. Sports Sci., 36(7), 749-756. doi: 10.1080/ 02640414.2017.1340655

[5] Cairney, J., Veldhuizen, S., Kwan, M., Hay, J., \& Faught, B. E. (2014). Biological age and sex-related declines in physical activity during adolescence. Med. Sci. Sports Exerc., 46(4), 730-735, doi: 10.1249/MSS.0000000000000168

[6] Carter, J. L., \& Heath, B. H. (1990). Somatotyping - development and applications. Cambridge: University Press.

[7] Carvalho, L. A., Klentrou, P., da Luz Palomero, M., \& Lebre, E. (2012). Body composition profile of elite group rhythmic gymnasts. Science of Gymnastics Journal, 4(1), 21-32.

[8] Cumming, S. P., Standage, M., Loney,T., Gammon, C., Neville, H., Sherar, L. B., \& Malina, R. M. (2011). The mediating role of physical self-concept on relations between biological maturity status and physical activity in adolescent females. Journal of Adolescence, 34(3), 465-473. doi: 10.1016/ j.adolescence.2010.06.006

[9] Davydov, V. Yu., Antonova, E. A., \& Vrublevsky, E. P. (2013). Estimates of the main aspects of the prospects of young athletes in acrobatics. Physical culture, sports and health of the nation, 15, 311-317.

[10] Davyidov, V. Yu., Trifonov, A. G., \& Shamardin, A. A. (2014). Technology selection, sports orientation and acquisition of acrobatic groups at different stages of training: a training manual for educational institutions of higher professional education, carrying out educational activities in areas 034300 (62) - "Physical Education". Volgograd: FGBOU VPO "Volgograd State Academy of Physical Culture".

[11] Di Rienzo, F., Collet, C., Hoyek, N., \& Guillot, A. (2014). Impact of neurologic deficits on motor imagery: a systematic review of clinical evaluations. Neuropsychol. Rev., 24(2), 116-147. doi: 10.1007/s11065-014-9257-6

[12] Di Rienzo, F., Guillot, A., Daligault, S., Delpuech, C., Rode, G., \& Collet, C. (2014). Motor inhibition during motor imagery: a MEG study with a quadriplegic patient. Neurocase, 20(5), 524539. doi: $10.1080 / 13554794.2013 .826685$

[13] Di Rienzo, F., Hoyek, N., Collet, C., \& Guillot, A. (2014). Physiological changes in response to apnea impact the timing of motor representations: a preliminary study. Behavioral and Brain Functions, 10(1), 15. doi: 10.1186/1744-9081-10-15
$80 \%$ ) and in the range of $19 \%$ of them the mesomorphic type was presented. In the postpubertal period of ontogenesis, acrobats belonged to 5 somatotypes, the ecto-mesomorphic type $(42.2 \%)$, mesomorphic was in $35.4 \%$, ectomorphic - in $7.7 \%$, endo-mesomorphic - in $2.2 \%$, middle intermediate was in $15.5 \%$ girls. In the control group there were more variants of somatotypes, but the tendency of predominance of the ectomesomorphic type is also characteristic for them.

[14] Erlandson, M. C., Mirwald, R. L., Sherar, L., \& Maffulli, N. (2008). Growth and maturation of adolescent female gymnasts, swimmers, and tennis players. Medicine \& Science in Sports \& Exercise, 40(1), 34-42. doi: 10.1249/ mss.0b013e3181596678

[15] Eyer, M., Dainat, B., Neumann, P., \& Dietemann, V. (2017). Social regulation of ageing by young workers in the honey bee, Apis mellifera. Experimental Gerontology, 87, 84-91. https://doi.org/10.1016/j.exger.2016.11.006.

[16] Freitas, A. S., Figueiredo, A. J., deFreitas, A. L., Rodrigues, V. D., daCunha, A. A., Deusdara, F. F. ... Silva, M. J. (2014). Biological Maturation, Body Morphology and Physical Performance in 8-16 year-old obese girls from Montes Claros - MG. J. Hum. Kinet., 43, 169-176. doi: 10.2478/hukin-20140102

[17] Guillot, A., Moschberger, K., \& Collet, C. (2013). Coupling movement with imagery as a new perspective for motor imagery practice. Behav Brain Funct., 9, 8. doi: 10.1186/17449081-9-8

[18] Kanthack, T. F. D., Guillot, A., Papaxanthis, C., Guizard, T., Collet, C., \& DiRienzo, F. (2017). Neurophysiological insights on flexibility improvements through motor imagery. Behav. Brain Res., 331, 159-168. doi: 10.1016/j.bbr.2017.05.004

[19] Linpei, J., Weiguang, Z., \& Xiangmei, C. (2017). Common methods of biological age estimation. Clin. Interv. Aging, 12, 759-772. doi: 10.2147/CIA.S134921

[20] Mateo, S., Di Rienzo, F., Reilly, K. T., Revol, P., Delpuech, C., Daligault, S. ... Rode, G. (2015). Improvement of grasping after motor imagery in C6-C7 tetraplegia: A kinematic and MEG pilot study. Restor. Neurol. Neurosci., 33(4), 543-555. doi: 10.3233/RNN-140466

[21] Pastuszak, A., Busko, K., \& Kalka, E. (2016). Somatotype and body composition of volleyball players and untrained female students - reference group for comparison in sport. Anthropological Review, 79(4), 461-470.

[22] Raković, A., Savanović, V., Stanković, D., Pavlović, R., Simeonov, A., \& Petković, E. (2015). Analysis of the elite athletes somatotypes. Acta Kinesiologica, 1, 47-53.

[23] Richert, S., Wehr, N. B., Stadtman, E. R., \&Levine, R. L. (2002).Assessment of skin carbonyl content as a noninvasive measure of biological age. Archives of Biochemistry and Biophysics, 397(2), 430-432. https://doi.org/10.1006/ abbi.2001.2683

[24] Stanković, D., Pavlović, R., Petković, E., Raković, A., \& Puletić, M. (2018). The somatotypes and body composition of elite track and field athletes and swimmers. International Journal of Sports Science, 8(3), 67-77. doi: 10.5923/ j.sports. 20180803.01

[25] Yakusheva, Y. I., \& Sarafinyuk, L. A. (2014). Features of total and separate partial anthropometric sizes in volleyball players of adolescence. Reports of Morphology, 20(2), 473-475. 


\section{СОМАТОТИПОЛОГІЧНІ ОСОБЛИВОСТІ АКРОБАТОК У РІЗНІ ПЕРІОДИ ОНТОГЕНЕЗУ}

\section{Сарафинюк Л. А., Хапіцька О. П., Якушева Ю. І., Іваниця А. О., Сарафинюк П. В.}

Соматотипологічна характеристика акробаток у літературі розкрита недостатньо, особливо з позиції ролі спортивного відбору, тренувальної та змагальної діяльності в становленні соматотипу у спортсменок, профресійна діяльність яких відзначається координацією, ритмічністю, артистичністю рухів і раннім початком впливу інтенсивних фрізичних навантажень на їх організм. Мета роботи - встановити особливості компонентів соматотипу акробаток високого рівня спортивної майстерності препубертатного, пубертатного та постпубертатного віку. Нами було проведено обстеження 122 акробаток високого рівня спортивної майстерності. У якості контрольної групи було обстежено 126 дівчаток, що не займалися спортом, із шкіл м. Вінниці. Паспортний вік досліджуваних був від 8 до 21 року. 3 метою визначення біологічного віку використали схему Автандилова Г. Г. (1990). Обстежені були розділені у відповідності зі ступенем біологічної зрілості на три групи: препубертатного періоду (36 акробаток і 39 дівчаток контрольної групи); пубертатного періоду (31 акробатка i 35 дівчаток контрольної групи); постпубертатного періоду (55 акробаток і 59 дівчат контрольної групи). Соматотипологічне дослідження проведено за розрахунковою модифрікацією метода Heath-Carter (1990). Аналіз отриманих результатів проведено у ліцензійному пакеті "Statistica 5.5" з використанням параметричних методів оцінки показників. Виявлено, що у препубертатному періоді онтогенезу в акробаток груповий соматотип був екто-мезоморфрним, а у дівчаток, які не займалися спортом, він був ектоморфнним. У даному періоді в акробаток жировий компонент соматотипу достовірно менший, а мезоморфний - достовірно більший, ніж у осіб, які не займалися спортом. У пубертатному періоді як в акробаток, так $і$ в контролі груповий соматотип був екто-мезоморфним. Виявлено, що акробатки у даному періоді мали більшу лінійність тіла, про що свідчать достовірно більші значення у них ектоморфрного компоненту соматотипу. Крім того, у спортсменок величина ендоморфного компонента була достовірно меншою, ніж в контрольній групі. В постпубертатний період онтогенезу величина F- i L-компонентів, на відміну від попереднього періоду, який характеризується інтенсивним пубертатним розвитком, достовірно не відрізнялися. Акробатки лише відзначалися достовірним переважанням мезоморфного компонента соматотипу. Можна зробити висновок, що особливості акробатичної спортивної діяльності в препубертатному, пубертатному та постпубертатному віці мають найбільш відчутний вплив на розвиток жирового і м'язового компонентів соматотипу.

Ключові слова: соматотип, спортивна акробатика, періоди онтогенезу, дівчата.

\section{СОМАТОТИПОЛОГИЧЕКИЕ ОСОБЕННОСТИ АКРОБАТОК В РАЗНЫЕ ПЕРИОДЫ ОНТОГЕНЕЗА \\ Сарафинюк Л. А., Хапицкая О. П., Якушева Ю. И., Иваница А. А., Сарафинюк П. В.}

Соматотипологическая характеристика акробаток в литературе раскрыта недостаточно, особенно с позиции роли спортивного отбора, тренировочной и соревновательной деятельности в становлении соматотипа у спортсменок, профессиональная деятельность которых отмечается координацией, ритмичностью, артистичностью движений и ранним началом воздействия интенсивных фризических нагрузок на их организм. Цель работы - установить особенности компонентов соматотипа акробаток высокого уровня спортивного мастерства препубертатного, пубертатного и постпубертатного возраста. Нами было проведено обследование 122 акробаток высокого уровня спортивного мастерства. В качестве контрольной группы были обследованы 126 девочек, не занимающихся спортом из школ г. Винницы. Паспортный возраст исследуемых был от 8 до 21 года. С целью определения биологического возраста использовали схему Автандилова Г. Г. (1990). Обследованы были разделены в соответствии со степенью биологической зрелости на три группы: подросткового периода (36 акробаток и 39 девочек контрольной группы); пубертатного периода (31 акробатка и 35 девочек контрольной группы); постпубертатного периода (55 акробаток и 59 девушек контрольной группы). Соматотипологическое исследование проведено по расчетной модификации метода Heath-Carter (1990). Анализ полученных результатов проведен в лицензионном пакете "Statistica 5.5" с использованием параметрических методов оценки показателей. Выявлено, что в препубертатном периоде онтогенеза у акробаток групповой соматотип был экто-мезоморфным, а у девочек, которые не занимались спортом, он был эктоморфрным. В данном периоде у акробаток жировой компонент соматотипа достоверно меньще, а мезоморфный - достоверно больще, чем у лиц, не занимающихся спортом. В пубертатном периоде у акробаток и в группе контроля групповой соматотип был экто-мезоморфным. Выявлено, что акробатки в данном периоде имели большую линейность тела, о чем свидетельствуют достоверно большие значения в них эктоморфного компонента соматотипа. Кроме того, у спортсменок величина эндоморфного компонента была достоверно меньще чем в контрольной группе. $B$ постпубертатный период онтогенеза величина F- и L-компонентов, в отличие от предыдущего периода, который характеризуется интенсивным пубертатным развитием, достоверно не отличались. Акробатки только отличались достоверным преобладанием мезоморфного компонента соматотипа. Можно сделать вывод, что особенности акробатической спортивной деятельности препубертатном, пубертатном и постпубертатном возрасте имеют наиболее ощутимое влияние на развитие жирового и мышечного компонентов соматотипа.

Ключевые слова: соматотип, спортивная акробатика, периоды онтогенеза, девушки. 